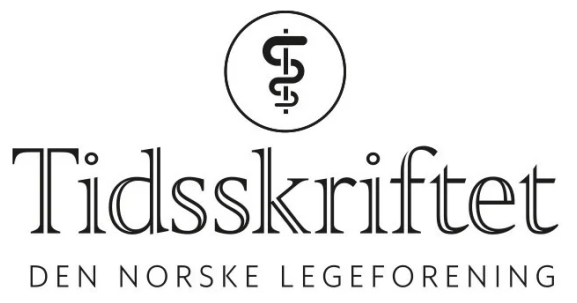

\title{
Kompleks genetikk ved kreft hos barn
}

FRA ANDRE TIDSSKRIFTER

\section{RUTH HALSNE}

Tidsskriftet

Kompleksiteten ved kreft hos barn er like stor som ved kreft hos voksne. 


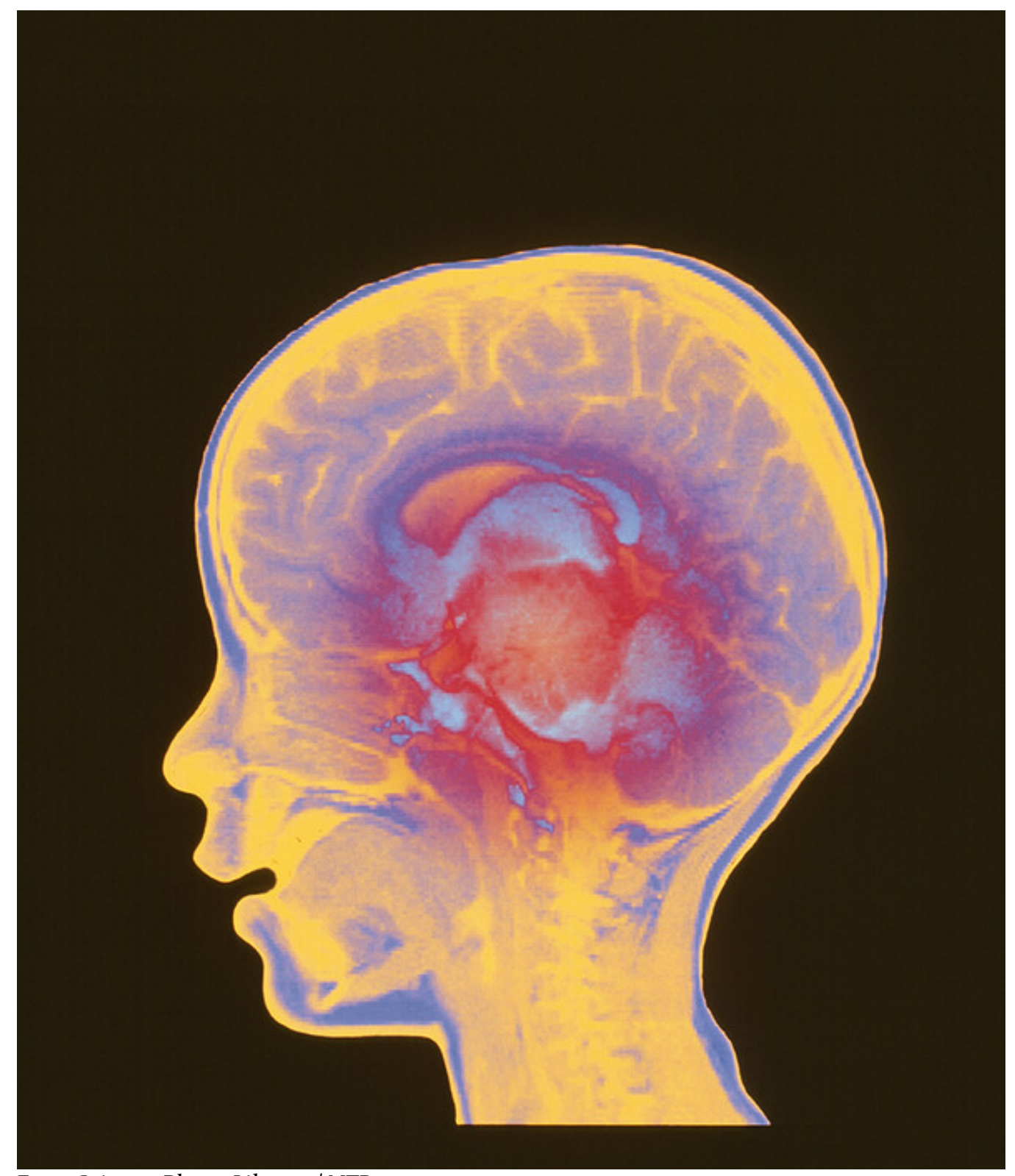

Foto: Science Photo Library / NTB

Flere studier har vist at hjernesvulster hos barn har færre mutasjoner enn hjernesvulster hos voksne. I en ny studie ble 82 kreftcellelinjer fra barn kartlagt og sammenlignet med kreftcellelinjer fra voksne (1). En omfattende genomisk karakterisering bekreftet at mutasjonsprofilene i cellelinjer i stor grad gjenspeiler tidligere funn ved barnesvulster med lavere mutasjonsbyrde enn hos voksne. Deretter ble genredigeringsverktøyet CRISPRCasg brukt til å gjøre en omfattende undersøkelse for å identifisere hvilke gener som var viktige for cellenes overlevelse. Til tross for en lavere mutasjonsbyrde hos barn var den genetisk betingede overlevelsen like kompleks som hos voksne.

- Kreftdrivende gener oppdaget ved bruk av CRISPR-Cas9-teknologi i cellelinjer kan vise veien til målrettet behandling ved barnekreft, sier Thomas Fleischer, som er forsker ved Oslo universitetssykehus og jobber med bl.a. professor Vessela Kristensen ved Universitetet i Oslo og Sebastian Waszak ved Norsk senter for molekylærmedisin.

- I denne studien viser forfatterne at cellelinjer med opphav fra barnekreft gjenspeiler virkelige kreftsvulster rimelig godt. I tillegg finner forfatterne gener som er viktigere i barnekreft enn i kreft hos voksne, f.eks. HDAC2 og IGF1R. Studien tyder også på at CDK4/6hemmere, som allerede er i klinisk bruk, kan være lovende behandling mot noen typer barnekreft, sier Waszak. 
- Til tross for at kreftsvulster hos barn har færre mutasjoner enn kreftsvulster hos voksne, må det like mange kreftgener til for at cellene skal overleve. Dette tyder på at mutasjonsbyrden i kreftsvulster hos voksne ikke reflekterer svulstens kompleksitet, men heller mutasjoner som akkumuleres under aldring, forteller de norske forskerne.

- Studiens begrensninger er at den i hovedsak dreier seg om cellelinjer fra nevroblastom og sarkom, mens de fleste tilfeller av kreft blant barn er hjernesvulst eller leukemi. I tillegg er p53-muterte cellelinjer overrepresentert i materialet, og analysene kan ikke skille mellom cytotoksisitet og cytostatisk effekt. Videre studier bør belyse den biologiske effekten av genene som ble identifisert i studien, sier de.

\section{LITTERATUR}

1. Dharia NV, Kugener G, Guenther LM et al. A first-generation pediatric cancer dependency map. Nat Genet 2021; 53: 529-38. [PubMed][CrossRef]

Publisert: 23. september 2021. Tidsskr Nor Legeforen. DOI: 10.4045/tidsskr.21.0544

(C) Tidsskrift for Den norske legeforening 2023. Lastet ned fra tidsskriftet.no 26. april 2023. 